\title{
Morphometric analysis of honey bees from an area of racial hybridization in northeastern Italy
}

\author{
F Nazzi \\ Istituto di Difesa delle Piante dell'Università di Udine, Area Rizzi, \\ via Fagagna 209, 33100 Udine, Italy
}

(Received 21 May 1991; accepted 27 December 1991)

\begin{abstract}
Summary - A morphometric analysis of some bee populations from Friuli (northeastern Italy) was carried out employing 15 fore-wing characters. Samples of $A m$ ligustica and $A m$ carnica, collected from the respective distribution areas, were also analyzed. On the grounds of the results obtained from a discriminant analysis and a cluster analysis of the Mahalanobis distances, it can be confirmed that the Friuli populations studied are hybrids between $A m$ ligustica and $A m$ carnica.
\end{abstract}

A m carnica / A m ligustica / morphometry / northeastern Italy

\section{INTRODUCTION}

In the alpine region of Italy 3 subspecies of Apis mellifera $\mathrm{L}$ come into contact: $A \mathrm{~m}$ ligustica Spinola, A m carnica Pollmann and $A m$ mellifera Linnaeus (Ruttner, 1988). Hybridization between $A$ m ligusti$c a$ and $A m$ carnica or $A m$ mellifera occurs in some parts of this region (Bolchi Serini et al, 1982; Leporati et al, 1984; Marletto et al, 1984). Friuli, in northeastern Italy, is regarded as a zone of hybridization between $A m$ carnica and $A m$ ligustica (Bolchi Serini et al, 1983; Comparini and Biasiolo, 1991).

Biochemical and morphometric techniques were employed to study samples of Friuli bees. Electrophoretic studies found 5 loci to be polymorphic (Comparini and Biasiolo, 1991). Est-6 appeared to be the most distinctive between $A m$ ligustica and $A m$ carnica (Biasiolo and Comparini, 1990). Apart from the pigmentation, the morphological differences between the Italian and the Balkan bee are rather slight; differences were found in abdominal dimensions, length of proboscis, hair length and several venation angles (Ruttner, 1988). Up to now, only one morphometric analysis has been carried out on bee samples from Friuli, employing 10 characters; 4 of these were fore-wing characters (Bolchi Serini et al, 1983).

The purpose of the present research was to acquire additional information on the bee populations of Friuli indicating their relative position among the races of neighbouring areas by means of morphometric analysis.

\section{MATERIALS AND METHODS}

Samples of adult worker bees ( 5 bees per hive) were collected during the summers of 19871989 from 106 colonies belonging to 11 apiaries located in Bologna and Reggio Emilia (in 
the distribution area of $\boldsymbol{A} m$ ligustica) Zagreb and Neumarkt ( $A m$ carnica) and in Friuli (Cervignano, Villa Santina, Ovaro, Prato Carnico, San Leopoldo, Camporosso) (fig 1). Neumarkt is located in a region formerly belonging to the distribution area of $A m$ mellifera, which was replaced by $A m$ carnica during the last decades (Ruttner, 1988). In the selected apiaries no queen importation or hive moving has taken place recently. The bees were captured at the hive entrance and stored at $-40^{\circ} \mathrm{C}$. The right fore-wing was cut off at the base and drymounted onto slides. Microphotographs of the slides (5 $\times$ magnification) were projected and the midline crossing points of the veins marked on a sheet of paper. The coordinates of these points were measured with a digitizer. The distances and angles were calculated with a computer program developed for this purpose that checked possible accidental errors.

\section{Characters employed}

Fifteen characters of the right fore-wing (fig 2) were used in this study because the body was employed for the electrophoretic study of the same populations (Comparini and Biasiolo, 1991); furthermore, 8 of the 13 useful characters for discriminating the races of the group to which $A m$ carnica and $A m$ ligustica belong are in the fore-wing (Ruttner, 1988).

The following characters (Bruckner, 1976; Ruttner et al, 1978) were used: 1) cubital vein, distance a; 2) cubital vein, distance b; 3) distance $\mathrm{c}$; 4) distance $d ; 5$ ) angle $A 4$; 6) angle $B 4$; 7) angle $D 7 ; 8$ ) angle $E 9 ; 9)$ angle $G 18 ; 10$ ) angle $J 10 ; 11$ ) angle $J 16$; 12) angle $\mathrm{K} 19 ; 13$ ) angle L13; 14) angle N23; 15) angle 026.

The distances $c$ and $d$, already used in studies on fluctuating asymmetry (Bruckner, 1976;

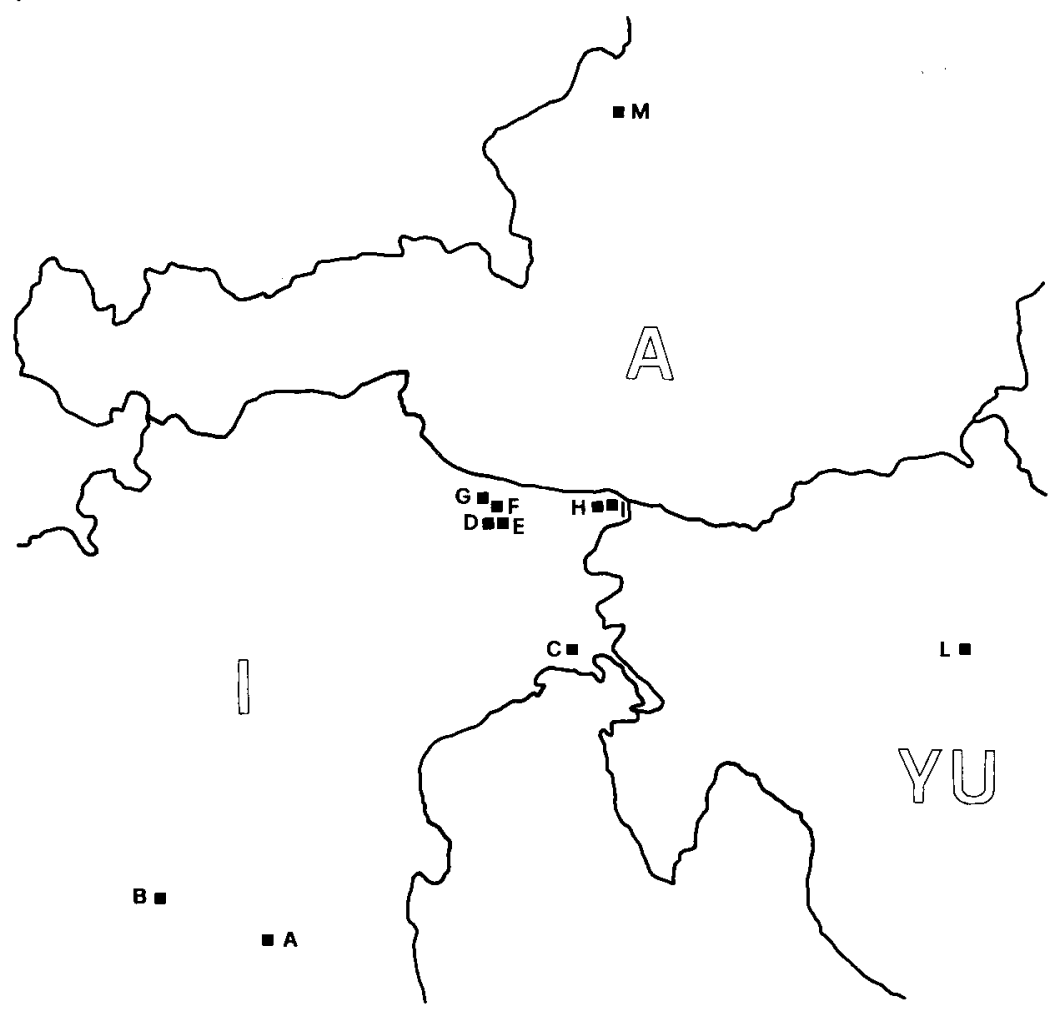

Fig 1. Geographic location of sampling localities. A m ligustica: A: Bologna; B: Reggio Emilia; Friuli samples: C: Cervignano; D: Villa Santina a; E: Villa Santina b; F: Ovaro; G: Prato Carnico; H: San Leopoldo; I: Camporosso; A m carnica: L: Zagreb; M: Neumarkt. 


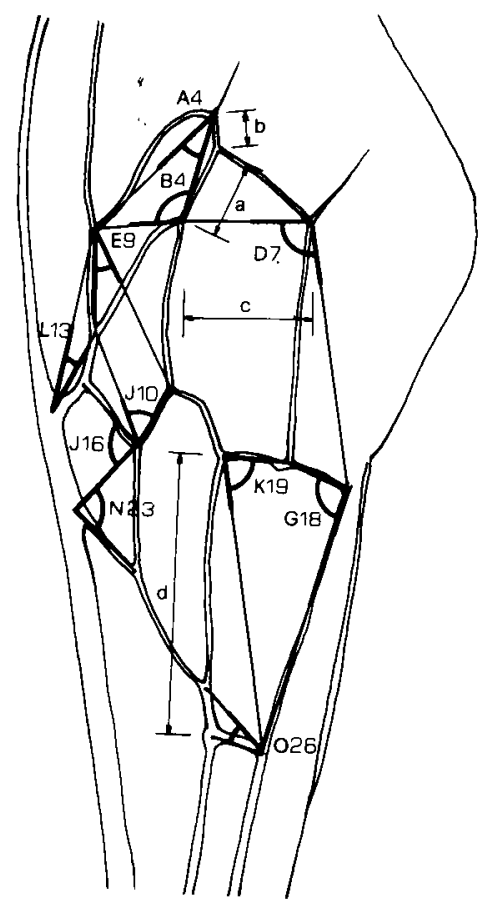

Fig 2. Wing characters measured.

Clarke et al, 1986), were employed instead of fore-wing length and width, which can be difficult to measure, due to imperfect amputations or natural consumption of the wing apex.

\section{Statistical analysis}

For each apiary, the mean and the standard deviation of each character was calculated.

For further statistical analyses the mean of the colony characters rather than the individual values were used. An ANOVA test was performed to determine the differences among the 3 groups of samples: those from the distribution area of $A$ m ligustica, those from the distribution area of $A \boldsymbol{m}$ carnica, and the Friuli samples. To determine the relative position of the samples, a multivariate discriminant analysis was carried out. Three ellipses of equal concentration $(P=$ 0.05 ; Langonegro and Feoli, 1985) were superimposed on the ordination scattergram: one for the ligustica, one for the carnica and one for the Friuli hives.
The generalized squared distance of Mahalanobis among the apiaries was then calculated and a dendrogram constructed by means of UPGMA (Sneath and Sokal, 1973).

The package for Data Analysis SYN TAX IV (Podani, 1990a, 1990b) and the statistical package SAS-PC (SAS Institute, 1988) were used for data analysis.

\section{RESULTS AND DISCUSSION}

The descriptive statistics for each apiary are reported in table I. For some characters (distance a, cubital index, angles D7, J16, L13, N23) an appreciable difference between ligustica and carnica samples can be observed, while the Friuli samples have intermediate values. The observed differences tested by ANOVA are highly significant $(P<0.001)$.

On the plane of discriminant functions 1 and 2 the hives are very dispersed; in spite of this, the ellipses of ligustica and carnica are well separated (fig 3). The Friuli populations have an intermediate position between those of ligustica and carnica, and the respective ellipse partially overlaps the 2 others.

Some observations may be made on the Mahalanobis distances matrix and the UPGMA dendrogram (table II; fig 4):

- some apiaries located in neighbouring sites showed unexpectedly low levels of similarity (samples $\mathrm{G}$ and F);

- the sample collected in Neumarkt (M) was more similar to 2 Friuli samples $(H, I)$ than to the other carnica sample collected in Zagreb (L).

Both these facts may be due to beekeeping practices (eg importation of carnica or ligustica queens from their distribution areas in the zone surrounding the sampled apiaries) that may have affected the studied populations.

Therefore, because of this kind of perturbation, it seems more realistic to consid- 


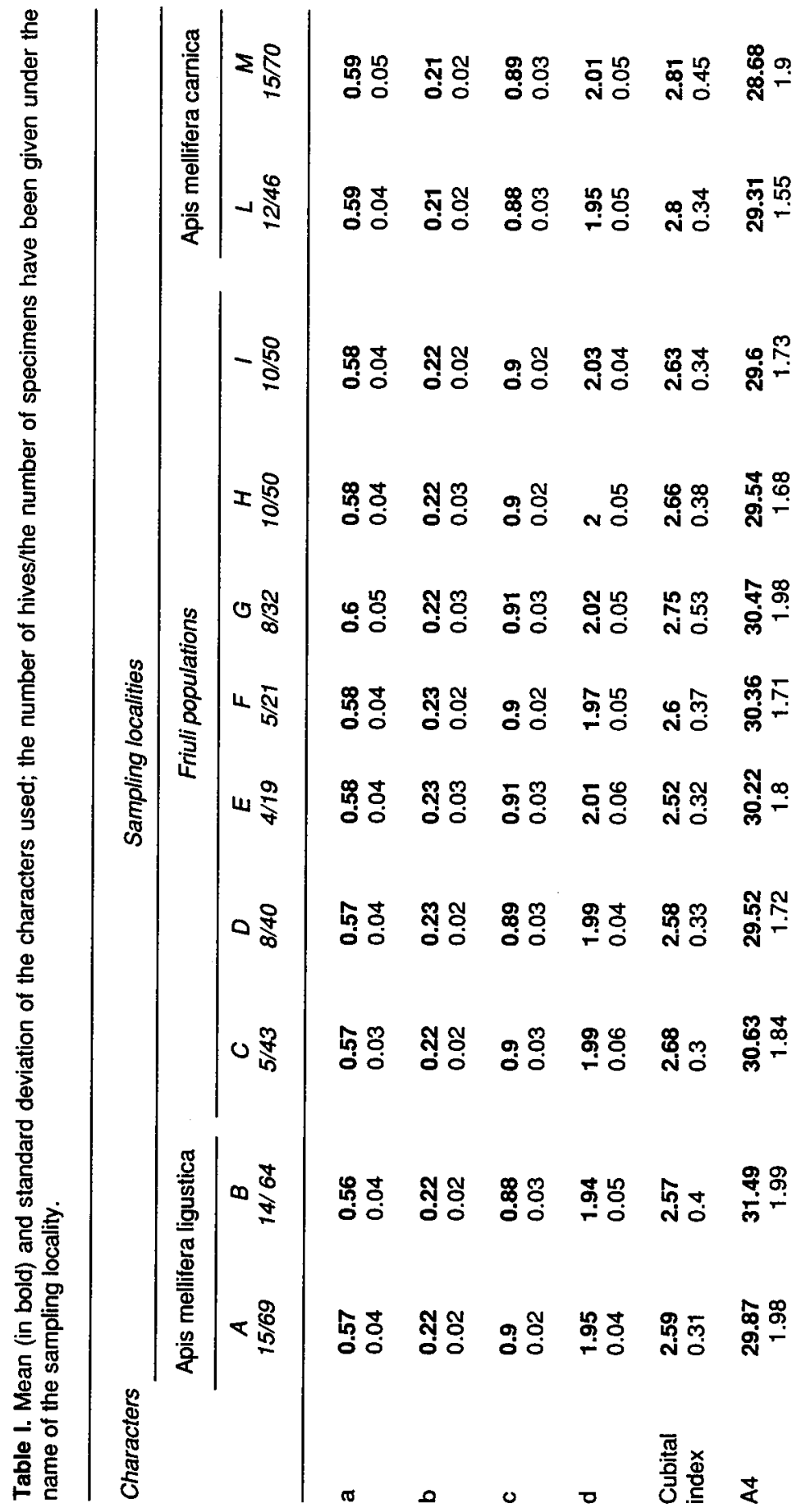




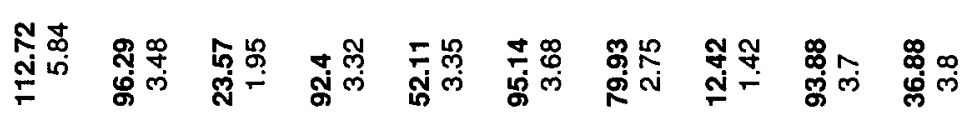

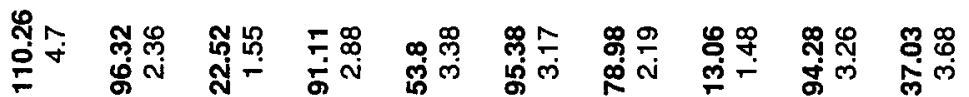

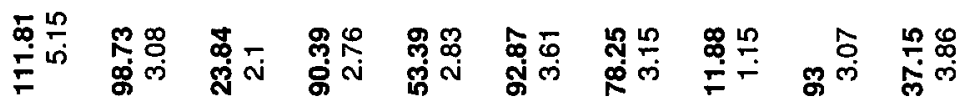

突志 范

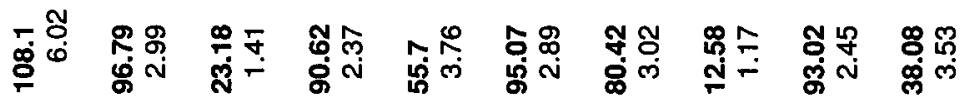

ఫั户

商 品

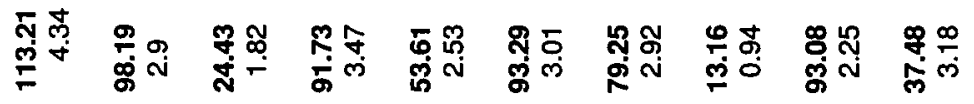

茞 吕

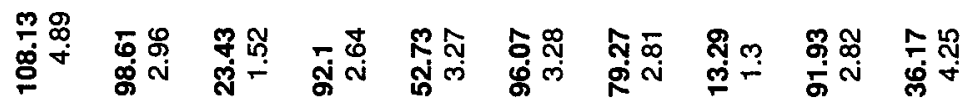

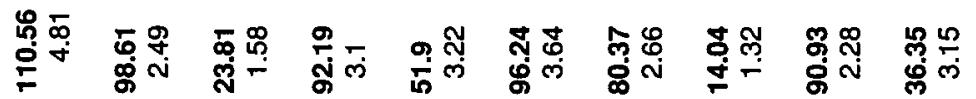

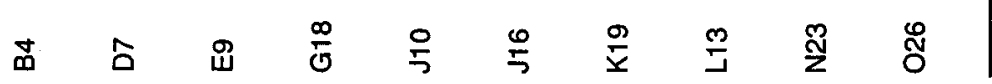




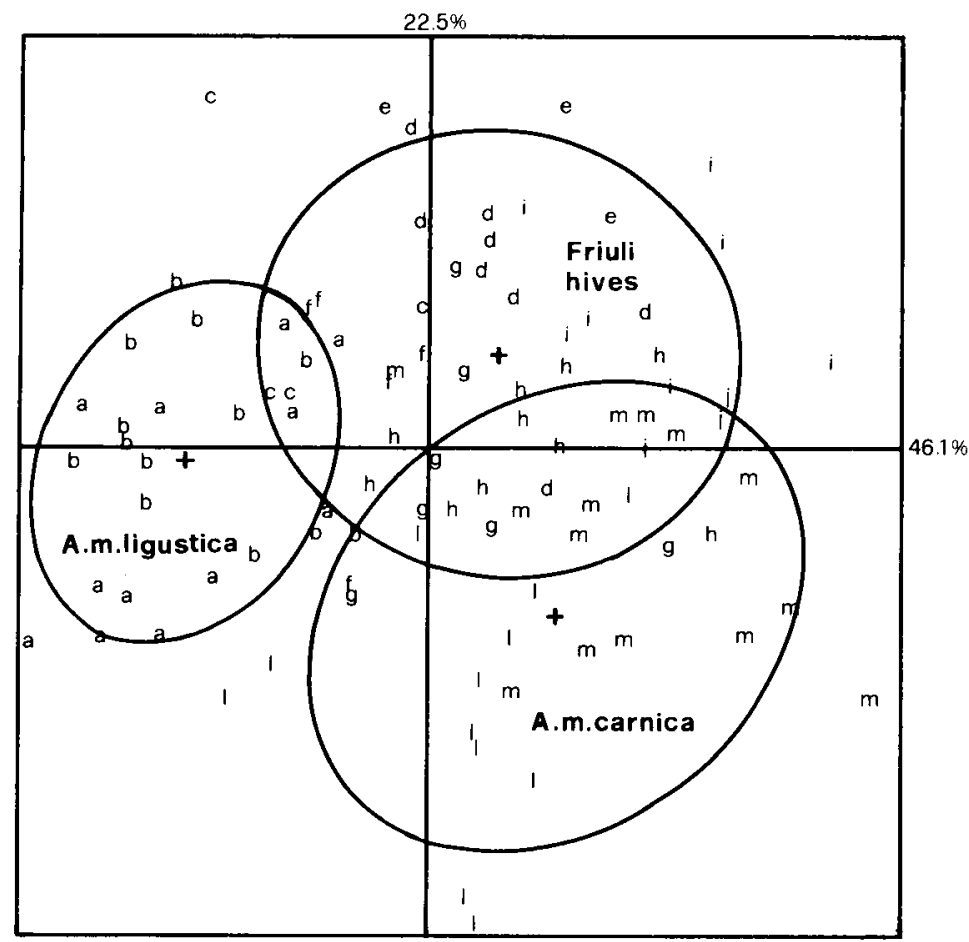

Fig 3. Discriminant analysis of the 106 hives considered; lettering is the same as in figure 1 (some symbols of the hives overlap, so 8 hives do not appear in the figure).

er only the biggest clusters of the dendrogram and disregard the small divisions; in this way the $A m$ carnica and $A m$ ligustica apiaries fall into 2 clearly distinct clusters; some Friuli populations resemble $A m$ ligustica, while others are more similar to A m carnica (fig 4).
On the grounds of these results it can be confirmed that the sampled Friuli populations are hybrids between $A m$ ligustica and $A$ m carnica.

In spite of the slight morphological differences between $A m$ ligustica and $A m$ carnica, the characters used can disting-

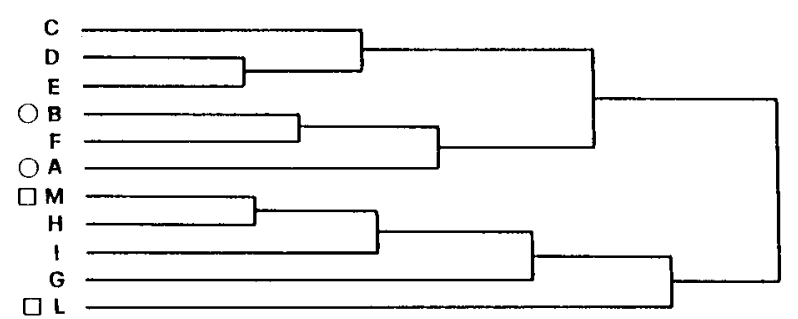

Fig 4. Dendrogram based on the Mahalanobis distances amiong the apiaries (the lettering is the same as in figure 1). Key to races: $A$ m carnica $\square ;$ A m ligustica $O$; Friuli populations are not marked. 
Table II. Mahalanobis distances matrix.

\begin{tabular}{|c|c|c|c|c|c|c|c|c|c|c|c|}
\hline & $A$ & $B$ & $c$ & $D$ & $E$ & $F$ & $G$ & $H$ & 1 & $L$ & $M$ \\
\hline $\begin{array}{l}A \\
B \\
C \\
D \\
E \\
F \\
G \\
H \\
I \\
L \\
M\end{array}$ & 0 & $\begin{array}{l}7.24 \\
0\end{array}$ & $\begin{array}{c}13.16 \\
8.59 \\
0\end{array}$ & $\begin{array}{c}19.13 \\
14.55 \\
7.34 \\
0\end{array}$ & $\begin{array}{r}17.96 \\
13.93 \\
6.46 \\
3.98 \\
0\end{array}$ & $\begin{array}{l}10.3 \\
5.36 \\
8.06 \\
6.86 \\
6.08 \\
0\end{array}$ & $\begin{array}{c}16.64 \\
16.55 \\
15.83 \\
14.14 \\
12.32 \\
8.03 \\
0\end{array}$ & $\begin{array}{l}13.94 \\
14.44 \\
11.2 \\
7.02 \\
7.65 \\
5.91 \\
6.18 \\
0\end{array}$ & $\begin{array}{c}30.21 \\
24.5 \\
19.26 \\
7.31 \\
9.56 \\
13.16 \\
13.11 \\
6.09 \\
0\end{array}$ & $\begin{array}{c}18.07 \\
15.01 \\
22.16 \\
17.66 \\
22.91 \\
11.55 \\
14.22 \\
10.43 \\
18.94 \\
0\end{array}$ & $\begin{array}{c}23.16 \\
23.41 \\
19.99 \\
11.58 \\
16.46 \\
15.04 \\
11.67 \\
4.21 \\
8.34 \\
10.29 \\
0\end{array}$ \\
\hline
\end{tabular}

uish between the races taken into consideration as shown by the discriminant analysis.

In addition, the measurement technique appears to be simple and rapid. It can therefore be suggested for studies which employ the fore-wing characters.

Résumé - Analyse morphométrique d'abeilles provenant d'une zone d'hybridation raciale dans le Nord-Est de l'italie. Le Frioul dans le Nord-Est de l'Italie est considéré comme une zone d'hybridation entre Apis mellifera ligustica et Apis mellifera carnica, mais jusqu'à présent une seule analyse morphométrique avait été réalisée sur des échantillons d'abeilles venant de cette région. Afin d'obtenir des informations supplémentaires sur les populations locales d'abeilles, nous avons fait une analyse morphométrique sur des abeilles prélevées dans le Frioul. Des échantillons d' $A m$ ligustica et d' $A m$ carnica récoltés dans leurs propres régions de répartition ont également été analysés (fig 1).

Cent six colonies réparties dans 11 ruchers différents ont été analysées, à raison de 5 abeilles par colonie, à l'aide de 15 caractères de l'aile antérieure (fig 2). Pour certains caractères, on a pu observer une différence appréciable entre $A m$ ligustica et $A m$ carnica, les populations du Frioul présentant des valeurs intermédiaires (tableau I).

Les données ont été analysées au moyen de l'analyse discriminante et de l'analyse par amas des distances de $\mathrm{Ma}$ halanobis. L'analyse discriminante montre que les échantillons d'abeilles du Frioul occupent une position intermédiaire entre celle de carnica et celle de ligustica (fig 3 ). Dans le dendogramme des distances de Mahalanobis (fig 4), on peut voir que certaines populations du Frioul ressemblent à A $m$ ligustica tandis que d'autres sont plus proches d'A $m$ carnica. Nous avons donc là la confirmation que les populations $d u$ Frioul étudiées sont des hybrides entre $A$ $m$ ligustica et $A$ m carnica.

\section{A m ligustica / A m carnica / morphomé- trie / Italie du Nord-Ouest}

\section{Zusammenfassung - Morphometrische} Analyse von Honigbienen in einem $\mathrm{Hy}$ bridisierungsgebiet von Rassen in Nord-Ost Italien. Friuli in Nord-Ost Italien wird als eine Hybridzone von Apis mellifera ligustica und Apis mellifera carnica betrachtet, aber bis jetzt wurde erst eine morphometrische Analyse von Bienenproben aus diesem Gebiet durchgeführt. Um zusätzliche Informationen über die lokalen 
Bienenpopulationen zu erhalten, wurde eine morphometrische Analyse mit Bienenproben aus Friuli durchgeführt. Proben von $A m$ ligustica und $A m$ carnica aus deren eigenen Verbreitungsarealen wurden ebenfalls analysiert (Abb 1).

106 Bienenvölker von 11 verschiedenen Bienenständen wurden berücksichtigt, wobei 15 Charaktere des Vorderflügels verwendet wurden (Abb 2). Bei einigen dieser Merkmale konnten deutliche Unterschiede zwischen $A m$ ligustica und $A m$ carnica beobachtet werden, während die Friuli Populationen zum Teil intermediäre Werte aufzeigen (Tabelle I).

Die Daten wurden mit einer Diskriminanz-Analyse und durch Gruppenbildung der Mahalanobis-Distanzen ausgewertet. Die Diskriminanz-Analyse erwies, daß die Bienenproben von Friuli eine intermediäre Position zwischen carnica und ligustica belegen (Abb 3). Im Dendrogramm der Mahalanobis-Distanzen (Abb 4) kann man erkennen, daß einige Populationen $A$ m ligustica ähneln, während andere mehr zu $A$ $m$ carnica tendieren. Die Abweichung der österreichischen Carnica-Proben von der erwarteten wird mit der Probenauswahl erklärt. Damit könnte bestätigt sein, daß die untersuchten Populationen von Friuli $\mathrm{Hy}$ briden zwischen $A m$ ligustica und $A m$ carnica sind.

\section{A m ligustica / A m carnica / Morphome- trie / Nordwestlich Italien}

\section{ACKNOWLEDGMENTS}

The author wishes to thank A Biasiolo for collecting the samples, $N$ Milani for useful suggestions on measurement techniques and $\mathrm{J}$ Rogers for revision of the English text.

This research was supported by a grant from the Ministero dell'Università $\theta$ della Ricerca Scientifica e Tecnologica (National Research Project (40\%): "Control and Improvement of Api- arian Products". Coordinator: Prof Romolo Prota, University of Sassari.

\section{REFERENCES}

Biasiolo A, Comparini A (1990) Esterase-6 locus, a new enzyme polymorphism in Apis mellifera. Apidologie 21, 123-126

Bolchi Serini G, Sommaruga A, Lapietra G (1983) Studio biometrico di popolazioni alpine di Apis mellifera L. Boll Zool Agrar Bachic II, 17, 1-18

Bruckner D (1976) The influence of genetic variability on wing symmetry in honeybees (Apis mellifera). Evolution 30, 100-108

Clarke GM, Brand GW, Whitten MJ (1986) Fluctuating asymmetry: a technique for measuring developmental stress caused by inbreeding. Aust J Biol Sci 39, 145-153

Comparini A, Biasiolo A (1991) Genetic characterization of Italian bee Apis mellifera ligustica Spin, versus Carnolian bee, Apis mellifera carnica Poll, by allozyme variability analysis. Biochem Syst Ecol 19, 189-194

Lagonegro M, Feoli $E$ (1985) The use of ellipses of equal concentration to analyse ordination vegetation patterns. Stud Geobot 5, 143-165

Leporati M, Valli M, Cavicchi S (1984) Étude biométrique de la variabilité géographique des populations d'Apis mellifera en Italie septentrionale. Apidologie 15, 285-302

Marletto F, Manino A, Balboni G (1984) Indagini biometriche su populazioni di Apis mellifera $\mathrm{L}$ delle Alpi occidentali. Apic Mod 75, 213-223

Podani J (1990a) SYN TAX IV. Computer Programs for Data Analysis in Ecology and Sys. tematics on IBM-PC and Macintosh Computers. CETA, Gorizia

Podani J (1990b) Supplementary Programs to SYN TAX IV. CETA, Gorizia

Ruttner F (1988) Biogeography and Taxonomy of Honeybees. Springer Verlag, Berlin

Ruttner F, Tassencourt L, Louveaux J (1978) Biometrical-statistical analysis of the geographic variability of Apis mellifera L. I. Materials and Methods. Apidologie 9, 363-381

SAS Institute (1988) User's Guide: Statistics. SAS Institute Inc, Cary, NC

Sneath PHA, Sokal RR (1983) Numerical Taxonomy. WH Freeman and Co, San Francisco, CA 